\title{
VALIDITAS BAHAN AJAR LKS MENULIS NASKAH DRAMA SISWA KELAS VIII SMP SE-KABUPATEN MUSI RAWAS
}

\author{
Sri Murti ${ }^{1} \&$ Muhtadin ${ }^{2}$ \\ ${ }^{1,2}$ Program Studi Pendidikan Bahasa dan Sastra Indonesia, STKIP PGRI Lubuklinggau \\ Jalan Mayor Toha, Air Kuti Telp. 451432 Kota Lubuklinggau, Sumatera Selatan, Indonesia \\ Email: srimurti05@gmail.com ${ }^{1}$, muhtadin.30@yahoo.com ${ }^{2}$
}

\begin{abstract}
Abstrak
Penelitian ini bertujuan mendeskripsikan validitas bahan ajar LKS menulis naskah drama siswa kelas VIII SMP se-Kabupaten Musi Rawas. Bahan ajar yang dikembangkan untuk meningkatkan minat belajar siswa kelas kelas VIII SMP se-Kabupaten Musi Rawas. Peneliti juga termotivasi untuk melakukan penelitian pengembangan ini karena ingin menambah referensi belajar dalam menulis naskah drama. Oleh sebab itu, peneliti ingin mengembangkan Lembar Kerja Siswa dengan contoh naskah drama yang berbasis cerita rakyat Musi Rawas. Metode yang digunakan yaitu metode penelitian dan pengembangan $(R \& D)$ dengan model Dick \& Carey yang dibatasi sampai 8 tahap. Validasi ahli dilakukan dengan tiga orang ahli, yaitu ahli validasi desain, ahli validasi kebahasaan, dan ahli validasi isi/materi. Instrumen penelitian dibagi atas: tes, angket, wawancara, kuesioner, skala penilaian dan skala sikap, observasi, dan sosiometri. Kegiatan penelitian pengembangan model bahan ajar ini, peneliti menggunakan instrumen pedoman tes, wawancara, kuesioner, dan lembar observasi untuk memvalidkan data penelitian. Hasil penelitian menunjukkan bahwa menunjukkan bahwa validitas bahan ajar LKS menulis naskah drama siswa kelas VIII SMP se-Kabupaten Musi Rawas termasuk dalam kategori baik dengan persentase $79,17 \%$ yang bersumber dari hasil ahli validasi desain, kebahasaan, dan materi. Dengan demikian, validitas bahan ajar LKS menulis naskah drama dalam penelitian ini dapat diterima kebenarannya. Bahan ajar LKS yang dikembangkan telah valid dan bahan ajar LKS setelah diujicobakan di sekolah dapat meningkatkan minat belajar menulis naskah drama siswa kelas VIII SMP se-Musi Rawas.
\end{abstract}

Kata kunci: validitas, bahan ajar LKS, menulis naskah drama

\section{THE VALIDITY OF LKS TEACHING MATERIALS WRITING DRAMA SCRIPTS FOR EIGHTH GRADE STUDENTS OF MUSI RAWAS REGENCY}

\begin{abstract}
This study aims to describe the validity of teaching materials LKS writing drama scripts for eighth-grade students of Musi Rawas Regency. Teaching materials developed to increase student interest in class VIII SMP throughout Musi Rawas Regency. Researchers are also motivated to conduct this development research because they want to add learning references in writing drama scripts. Therefore, the researcher wants to develop a Student Worksheet with examples of drama scripts based on the folklore Musi Rawas. The method used is the research and development (R\&D) method with the Dick \& Carey model which is limited to 8 stages. Expert validation was carried out with three experts, namely design validation expert, linguistic validation expert, and content/material validation expert. The research instruments were divided into the test, questionnaire, interview, questionnaire, rating scale, and attitude scale,
\end{abstract}


observation, and sociometry. Research activities in developing this teaching material model, researchers used test guideline instruments, interviews, questionnaires, and observation sheets to validate research data. The results showed that the validity of LKS teaching materials writing drama scripts for eighth-grade students of Musi Rawas Regency was included in the good category with a percentage of $79.17 \%$ originating from the results of design, language, and material validation experts. Thus, the validity of LKS teaching material writing drama scripts in this study can be accepted as correct. The LKS teaching materials developed were valid and the LKS teaching materials after being tested at school could increase the interest in learning to write drama scripts for eighth-grade students of Musi Rawas.

Keywords: validity, LKS teaching materials, writing drama scripts

\section{A. Pendahuluan}

Pengembangan bahan ajar dan media pembelajaran merupakan salah satu kewajiban yang harus disusun oleh guru untuk mengembangkan kompetensi sebagai guru yang profesional. Hal ini sesuai dengan pendapat Noermanzah (2015:274) bahwa tenaga pendidik salah satunya bertugas menyusun bahan ajar sesuai dengan kebutuhan peserta didik dan mampu memberikan pemahaman terhadap materi yang dituangkan dalam bahan ajar. Bahan ajar yang masih membutuhkan pengembangan yaitu bahan ajar naskah drama. Sebagai salah satu pembelajaran sastra yang terdapat pada kurikulum 2013 (K-13), materi menulis naskah drama ada pada kelas VIII SMP/MTs. Pembelajaran di Sekolah Menengah Pertama (SMP) salah satu kegiatan pembelajaran drama yang dilaksanakan adalah menulis naskah drama. Ternyata pada praktiknya masih ditemui hasil belajar yang di bawah KKM. Dapat diketahui dari hasil tersebut, kemampuan siswa di kelas VIII dalam menulis naskah drama masih sangat rendah. Diperkuat dari hasil observasi penulis pada beberapa sekolah yang membuat KKM sekolah pada materi menulis naskah drama sangat rendah. Untuk itu perlu adanya usaha untuk meningkatkan hasil pada belajar siswa tersebut dengan menulis bahan ajar yang kreatif dan inovatif.

Kegiatan di kelas dalam menyampaikan materi, seorang pendidik akan lebih menguasai kelas apabila menyampaikan materi dengan mengunakan bahan ajar. Bahan ajar sangat membantu dalam kegiatan belajar, adanya bahan ajar siswa juga lebih tertarik untuk mempelajari materi yang diajarkan oleh pendidik. Bahan ajar yang digunakan oleh guru sangat membantu peserta didik untuk dapat mempelajari suatu kompetensi yang utuh sehingga peserta didik mampu 
menguasai keseluruhan isi materi menulis naskah drama dengan mudah. Sejalan dengan pendapat Amri \& Ahmadi (2010:52) bahwa "Bahan ajar dipandang sebagai materi yang disediakan oleh kebutuhan pembelajaran yang mencakup buku teks, video dan audiotapes, softwere computer, dan alat bantu visual". Bahan ajar juga merupakan semua bentuk bahan yang digunakan untuk membantu guru atau instruktur dalam melaksanakan kegiatan belajar mengajar dengan baik (Noermanzah, 2019: 6631). Bahan yang dimaksud dapat berupa bahan tertulis maupun bahan tidak tertulis. Bahan ajar memiliki beragam jenis, ada yang cetak maupun noncetak. Bahan ajar cetak yang sering dijumpai antara lain berupa handout, buku, lembar kerja siswa (LKS), modul, dan brosur. Salah satunya bahan ajar LKS menulis naskah drama siswa kelas VIII SMP SeKabupaten Musi Rawas.

Menulis juga merupakan suatu keterampilan berbahasa yang digunakan untuk mengungkapkan pikiran, perasaan, pengalaman, dan peristiwa dalam bentuk tulisan bukan dalam bentuk lisan. Sejalan dengan pendapat Tarigan (2008:3), bahwa "Menulis merupakan suatu kegiatan yang produktif dan ekspresif". Menulis juga sebagai proses kreatif seseorang dalam bentuk tulisan yang memberikan manfaat kepada pembacanya (Fadhillah, 2019:134). Menurut pendapat Cahyani (2012:74), "Menulis adalah menyampaikan pesan (komunikasi) dengan menggunakan bahasa tulis sebagai alat atau medianya". Berdasarkan pendapat di atas, disimpulkan bahwa menulis adalah kegiatan yang dilakukan oleh seseorang untuk menghasilkan sebuah karya dalam bentuk tulisan. Menulis juga merupakan kegiatan yang menghasilkan sesuatu yang dapat melatih keterampilan seseorang khususnya keterampilan menuangkan ide dalam bentuk tulisan.

Menurut Endraswara (2011:37) "Naskah drama adalah kesatuan teks yang membuat kisah. Sebagai salah satu genre sastra, naskah drama dibangun oleh stuktur fisik (kebahasaan) dan struktur batin (semantik, makna). Lasmiyanti, dkk. (2019:53-54) menjelaskan bahwa kompetensi menulis naskah drama ini dapat dikuasai oleh peserta didik apabila dalam menulis naskah drama memperhatikan unsur intrinsik drama seperti dialog, alur, latar, tokoh, imajinasi, dan amanat. Riantiarno (2003:17) juga mengemukakan, "Naskah drama merupakan karya 
sastra yang bisa berdiri sendiri karena memiliki muatan sastra". Lakuan dialog dalam drama tidak jauh berbeda dengan lakuan dan dialog yang terjadi dalam kehidupan sehari-hari. Wujud fisik sebuah naskah drama adalah dialog atau ragam tutur. Dari pendapat ahli di atas, dapat dikatakan naskah drama merupakan karya sastra yang memiliki muatan sastra yang bisa berdiri dengan sendirinya dan tidak jauh dari lakuan dialog antar tokoh yang terjadi dalam kehidupan sehari-hari.

Proses pembelajaran naskah drama tidak akan terlepas dengan adanya materi pembelajaran dan bahan ajar yang digunakan. Sebuah materi pembelajaran naskah drama sangat berperan penting dalam kegiatan pembelajaran berlangsung. Dalam penelitian ini, penulis mencoba menulis dan mengembangkan bahan ajar menulis naskah drama berbasis cerita rakyat Musi Rawas yang sumbernya terdapat di Kabupaten Musi Rawas yang berbentuk Lembar kerja Siswa (LKS), tetapi dibatasi pada hasil validitas bahan ajarnya saja.

Penelitian relevan yang penulis gunakan yaitu penelitian dari Jannah (2016) dengan judul "Pengembangan LKS Bermain Drama Berbasis Autobiografi Habibie dan Ainun untuk Siswa Kelas XI SMA/MA". Persamaan yang terdapat pada penelitian ini dan hasil dari penulis yaitu sama-sama mengembangkan bahan ajar LKS. Perbedaan yang terdapat pada penelitian relevan adalah penelitian relevan ini menggunakan model Research and Development (R\&D) dengan tiga tahapan utama, yakni hasil studi pendahuluan, pengembangan produk, dan produk atau hasil pengembangan. Sedangkan peneliti menggunakan model Research and Development (R\&D) sampai delapan tahap.

Penelitian relevan berikutnya dengan judul "Pengembangan Media Pembelajaran Membaca Teks Drama untuk SMP Kelas VIII dengan MTGT (Metode Teams Games Tournament) Berbasis Software Adobe Flash" oleh Yogananta (2016), Jurusan Pendidikan Bahasa dan Sastra, Fakultas Bahasa dan Seni, Universitas Negeri Yogyakarta. Persamaan penelitian yang penulis gunakan yaitu penelitian ini sama-sama mengembangkan bahan ajar drama. Perbedaan dalam penelitian ini yaitu penelitian relevan mengembangkan KD membaca drama sedangkan peneliti mengembangkan KD menulis teks drama. 
Berdasarkan penelitian relevan maka penulis ingin mengembangkan bahan ajar LKS menulis teks drama siswa kelas VIII SMP Se-Kabupaten Musi Rawas. Faktor lain yang memotivasi penulis, dalam kegiatan penelitian ini yaitu penulis mendapatkan pengalaman mengajar dan belajar untuk menemukan langkahlangkah dalam membuat bahan ajar yang lebih inovatif dan menarik. Tampilan disajikan semenarik mungkin serta mudah untuk dipahami siswa, sehingga peserta didik akan termotivasi dalam meninggkatkan potensi belajar.

Masalah yang penulis ajukan adalah Bagaimanakah validitas bahan ajar LKS siswa kelas VIII SMP Se-Kabupaten Musi Rawas? Secara khusus rumusan masalah dalam penelitian ini adalah (1) Bagaimanakah mendesain bahan ajar siswa kelas VIII SMP Se-Kabupaten Musi Rawas? Kemduian, tujuan penelitian pengembangan bahan ajar LKS siswa kelas VIII SMP Se-Kabupaten Musi Rawas 1) Mengetahui proses mendesain mengembangkan bahan ajar LKS siswa kelas VIII SMP se-Kabupaten Musi Rawas yang valid.

\section{B. Metode Penelitian}

1. Model yang Dikembangkan

Penelitian pengembangan (Research \& Development) memiliki langkahlangkah yang menjadi pedoman sehingga harus diikuti dari langkah awal sampai langkah akhir. Langkah-langkah atau prosedural dapat kita jumpai dalam model rancangan sistem pembelajaran (Setyosari, 2013:112). Model rancangan sistem pembelajaran memiliki banyak ragamnya, seperti model Sugiyono, model Jolly Balitho, model Camp, model Dick \& Carey, dan lain sebagainya.

Model yang dirancang dan dikembangkan dalam penelitian ini menggunakan model Dick \& Carey sering digunakan dalam penelitian dan pengembangan secara luas, sehingga keberhasilan model Dick \& Carey juga telah teruji. Hal ini didasarkan pada pertimbangan kemampuan peneliti untuk menjalankan model Dick \& Carey dalam penelitian dan pengembangan modul apresiasi drama berbasis kearifan lokal.

Adapun langkah-langkah model rancangan sistem pembelajaran yang sistematis dan berkesinambungan harus diikuti. Begitu juga model yang dirancang dan dikembangkan oleh Dick \& Carey memiliki sepuluh langkah, yaitu : a) analisis 
kebutuhan dan tujuan; b) analisis pembelajaran; c) analisis pembelajaran (siswa) dan konteks; d) merumuskan tujuan performansi; e) mengembangkan instrumen; f) mengembangkan strategi pembelajaran; g) mengembangkan dan memilih bahan pembelajaran; h) merancang dan melakukan evaluasi formatif; i) melakukan revisi; dan j) evaluasi sumatif.

\section{Rancangan Model Pengembangan}

Peneliti akan memaparkan rancangan bahan ajar menulis naskah drama yang akan dikembangkan, melalui referensi yang telah peneliti siapkan. Hasil observasi yang telah peneliti lakukan, bahan ajar berbentuk menggunakan struktur bahan ajar cetak, yakni berupa Lembar Kerja Siswa (LKS). Penyusunan bahan ajar cetak menurut Amri dan Ahmadi (2010:67), harus memenuhi kriteria yaitu: susunan tampilan, bahasa yang mudah, menguji pemahaman, stimulan, kemudahan dibaca, dan materi instruksional sehingga menghasilkan bahan ajar cetak yang berkualitas.

Pengembangan model bahan ajar yang peneliti gunakan, menganut langkah-langkah pengembangan model bahan ajar menurut Dick \& Carey (dalam Setyosari, 2013), terdapat sepuluh langkah menurut model Dick and Carey, yaitu: 1) analisis kebutuhan dan tujuan; 2) analisis pembelajaran; 3) analisis pembelajar (siswa) dan konteks; 4) merumuskan tujuan performansi; 5) mengembangkan instrumen; 6) mengembangkan strategi pembelajaran; 7) mengembangkan dan memilih bahan pembelajaran; 8) merancang dan melakukan evaluasi formatif; 9) melakukan revisi; dan 10) evaluasi sumatif.

Batasan penelitian pengembangan LKS menulis naskah drama berbasis cerita rakyat Musi Rawas, yaitu SMP yang akan digunakan adalah SMP yang memiliki kriteria MTs, SMP Negeri dan SMP yayasan. Kemudian, pelaksanaan penelitian pengembangan ini hanya sampai pada langkah kedelapan yaitu merancang dan melakukan evaluasi formatif.

Instrumen penelitian dibagi atas; tes, angket, wawancara, kuesioner, skala penilaian dan skala sikap, obsevasi, dan sosiometri. Kegiatan penelitian pengembangan model bahan ajar ini, peneliti menggunakan intrumen wawancara, kuesioner dan observasi untuk memvalidkan data penelitian Susetyo (2010). 


\section{Hasil Penelitian dan Pembahasan}

\section{Hasil Penelitian}

Setelah diidentifikasi terdapat beberapa perbedaan LKS yang digunakan sebelumnya dengan LKS yang dikembangkan oleh penulis. Adapun letak perbedaannya sebagai berikut:

Tabel 1. Perbedaan Bentuk LKS Lama dengan Bentuk LKS Baru

\begin{tabular}{cll}
\hline No. & \multicolumn{1}{c}{ LKS Lama } & \multicolumn{1}{c}{ LKS Baru } \\
\hline 1. & Tidak ada cerita rakyat Musi Rawas & Ada cerita rakyat Musi Rawas \\
\hline 2. & Tidak memiliki ciri khas masih bersifat & $\begin{array}{l}\text { Memiliki ciri khas dengan } \\
\text { menampilkan contoh-contoh daerah } \\
\text { umum }\end{array}$
\end{tabular}

Penulis mengambil contoh cerita Musi Rawas yang sesuai dengan lingkungan tempat tinggal. Siswa akan lebih tertarik karena ceritanya asli dari daerah asalnya dan dapat mengenalkan kepada siswa yang nyaris tidak mengenal cerita daerah Musi Rawas.

Berikut ini ditampilkan standar kompetensi inti (KI) dan kompetensi dasar (KD) dalam bentuk tabel 2.

Tabel 2. Kompetensi Dasar Mata Pelajaran Bahasa Indonesia Kelas VIII Kompetensi Dasar (KD)

8.1 Mengungkapkan pikiran dan perasaan melalui kegiatan menulis kreatif naskah drama.

8.2 Menulis kreatif naskah drama dengan memperhatikan keaslian ide.

Identifikasi terhadap perilaku dan karakteristik siswa SMP Se-Kabupaten Musi Rawas meliputi kemampuan yang dimiliki oleh siswa dan sikap siswa terhadap aktivitas belajar. Dapat dilihat dari sikap siswa yang sangat antusias untuk mengikuti pembelajaran. Menarik siswa yang aktif untuk membuat pembelajaran menjadi efektif.

Tugas atau tes uji coba yang diberikan kepada siswa sebanyak satu soal, karena hanya mengukur satu kemampuan siswa dalam menulis teks drama. Langkah selanjutnya yang dilakukan yaitu mengembangkan rencana pelaksanaan pembelajaran (RPP), yang memasukkan strategi ceramah, tanya jawab, dan penugasan. Tahap terakhir dalam pengembangan LKS menulis naskah drama yaitu melakukan evalusi validasi ahli. Tahap evaluasi dan revisi dilakukan dalam beberapa kali uji coba, yaitu: 
a. Hasil Evaluasi Ahli

1). Hasil Validasi Desain

Validator ahli desain atau grafik bahan ajar LKS menulis naskah drama, adalah salah satu dosen dari STKIP-PGRI Lubuklinggau yang berkompeten dalam bidang desain yaitu Bapak Dr. Dodik Mulyono, M.Pd., dosen STKIP PGRI Lubuklinggau. Pertanyaan validasi desain terdiri dari sepuluh butir pertanyaan untuk mengevaluasi kelayakan penyajian bahan ajar LKS menulis naskah drama. Berdasarkan hasil validasi tim ahli terdapat beberapa perbaikan, yang pertama dari ahli desain yaitu peta konsep pada bahan ajar harus dibuat. Kedua tujuan menggunakan format ABCD. Ketiga pemilihan gambar atau ilustrasi harus sesuai materi. Terakhir pemilihan warna latar tulisan harus diperhatikan. Komponen kelayakan desain termasuk dalam kategori baik, dengan persentase $82 \%$ yang dapat ditunjukkan pada tabel berikut.

Tabel 3. Posisi Hasil Kelayakan Desain Bahan Ajar LKS Menulis Naskah Drama

\begin{tabular}{|c|c|l|}
\hline Rentang Nilai & Presentase & \multicolumn{1}{|c|}{ Kategori } \\
\hline $42-50$ & $84 \%-100 \%$ & Sangat Baik \\
\hline $\mathbf{3 4 - 4 1}$ & $\mathbf{6 8} \%-\mathbf{8 2} \%$ & Baik \\
\hline $26-33$ & $52 \%-66 \%$ & Cukup \\
\hline $18-25$ & $36 \%-50 \%$ & Kurang Sesuai \\
\hline $10-17$ & $20 \%-34 \%$ & Sangat tidak baik \\
\hline
\end{tabular}

2). Hasil Validasi Bahasa

Validator ahli selanjutnya yaitu ahli bahasa yang juga ahli di bidangnya diambil dari dsalah satu dosen UNIB yaitu Dr. Susetyo, M.Pd. Angket yang diberikan sama dengan ahli desain yaitu angket terbuka dengan sebelas pertanyaan. Kritik dan juga saran disediakan oleh peneliti supaya peneliti mendapatkan masukan, dalam perbaikan bahan ajar mengidentifikasi struktur teks narasi. Perbaikan dari ahli bahasa yang pertama penulisan harus dibaca lagi karena masih terdapat salah dalam pengetikan kata. Kedua kesalahan pada (spasi, pengetikan) perlu dicermati agar bisa berkualitas. Istilah asing harus ditulis dengan huruf miring. Komponen kelayakan kebahasaan termasuk dalam kategori baik, dengan persentase $72, \%$ yang dapat ditunjukkan pada tabel berikut. 
Tabel 4. Posisi Hasil Kelayakan pada Aspek Kebahasaan Bahan Ajar LKS Menulis Naskah Drama

\begin{tabular}{|c|c|l|}
\hline Rentang Nilai & \multicolumn{1}{|c|}{ Presentase } & \multicolumn{1}{|c|}{ Kategori } \\
\hline $29,4-35$ & $84 \%-100 \%$ & Sangat Baik \\
\hline $\mathbf{2 3 , 8 - 2 9 , 3}$ & $\mathbf{6 8} \%-\mathbf{8 3 , 7} \%$ & Baik \\
\hline $18,2-23,7$ & $52 \%-67,7 \%$ & Cukup \\
\hline $12,6-18,1$ & $36 \%-51,7 \%$ & Kurang Sesuai \\
\hline $7-12,6$ & $20 \%-35,7 \%$ & Sangat tidak baik \\
\hline
\end{tabular}

3). Hasil Validasi Ahli Materi

Evaluasi ahli materi dilakukan untuk mengetahui kelayakan dan keakuratan materi yang akan dipelajari oleh peserta didik. Validasi materi adalah seorang dosen yang ahli di bidangnya dan telah mengajar dalam kurun waktu yang lama, yaitu Ibu Dr. Rusmana Dewi, M.Pd. yang merupakan dosen Program Studi Pendidikan Bahasa dan Sastra Indonesia STKIP-PGRI Lubuklinggau. Evaluasi yang dilakukan sama dengan ahli sebelumnya yaitu menggunakan angket terbuka, terdiri dari empat belas pertanyaan. komponen kelayakan isi/materi termasuk dalam kategori Baik, dengan persentase $81 \%$ yang dapat ditunjukkan pada tabel berikut.

Tabel 5. Posisi Hasil Kelayakan Isi/Materi

Bahan Ajar LKS Menulis Naskah Drama

\begin{tabular}{|l|c|l|}
\hline Rentang Nilai & Presentase & \multicolumn{1}{c|}{ Kategori } \\
\hline $29,4-35$ & $84 \%-100 \%$ & Sangat Baik \\
\hline $\mathbf{2 3 , 8 - 2 9 , 3}$ & $\mathbf{6 8 \%}-\mathbf{8 3 , 7 \%}$ & Baik \\
\hline $18,2-23,7$ & $52 \%-67,7 \%$ & Cukup \\
\hline $12,6-18,1$ & $36 \%-51,7 \%$ & Kurang Sesuai \\
\hline $7-12,6$ & $20 \%-35,7 \%$ & Sangat tidak baik \\
\hline
\end{tabular}

Penghitungan keseluruhan validasi dari tiga ahli dari seluruh komponen kelayakan desain, bahasa, dan materi bahan ajar menulis naskah drama termasuk dalam kategori baik, dengan persentase 79,17\% yang dapat ditunjukkan pada tabel berikut.

Tabel 6. Hasil Keseluruhan Kelayakan Bahan Ajar LKS Menulis Naskah Drama dari Aspek Desain, Bahasa, dan Materi

\begin{tabular}{|l|l|l|}
\hline Rentang Nilai & Presentase & \multicolumn{1}{|c|}{ Kategori } \\
\hline $100,8-120$ & $84 \%-100 \%$ & Sangat Baik \\
\hline $\mathbf{8 1 , 6 - 1 0 0 , 7}$ & $\mathbf{6 8} \%-\mathbf{8 3 , 9} \%$ & Baik \\
\hline $62,4-81,5$ & $52 \%-67,9 \%$ & Cukup \\
\hline $43,2-62,3$ & $36 \%-51,9 \%$ & Kurang Sesuai \\
\hline $24-43,1$ & $20 \%-35,9 \%$ & Sangat tidak baik \\
\hline
\end{tabular}

Silampari Bisa: Jurnal Penelitian Pendidikan Bahasa Indonesia, Daerah, dan Asing Vol. 2, No. 2, 2019 


\section{b. Evaluasi Propotipe}

Pada langkah evaluasi one to one yang dilaksanakan pada tanggal 4 April 2019 dengan melakukan wawancara kepada tiga orang siswa. Langkah-langkah yang dilakukan dalam evaluasi one to one yaitu: 1) siswa diminta untuk membaca dan melihat-lihat sekilas bahan ajar menulis naskah drama; 2) siswa diminta untuk memperhatikan materi yang diambil secara acak sebagai contoh untuk ditanyakan; 3) selanjutnya siswa ditanya secara lisan tentang materi yang ada, sesuai, menarik, dan mudah atau sebaliknya.

Validasi one to one bahan ajar LKS menulis naskah drama terdapat beberapa kriteria yaitu: a) kemenarikan bahan ajar; b) keterbacaan isi materi; c) penyajian gambar; d) penyajian materi dalam bahan ajar LKS naskah drama. Evaluisi one to one ini dilakukan bertujuan untuk melihat kepraktisan penggunaan bahan ajar naskah drama.

Pelaksanaan uji one to one yang dilakukan oleh tiga orang siswa menyatakan bahwa bahan ajar naskah drama dapat memotivasi. Bahan ajar LKS naskah drama juga mendapat respons positif, materi yang disajikan mudah dipahami serta dapat menarik minat siswa untuk lebih mendalaminya. Pada gambar di bawah ini menunjukkan bahwa ada respons dari siswa tentang bahan ajar LKS naskah drama.

1). Pelaksanaan Evaluasi Kelompok Kecil

Pada langkah ini siswa mengisi angket tertutup dengan soal sebanyak 10 butir. Siswa yang dipilih secara acak ini dijadikan satu baris untuk mengisi angket yang telah dibagikan. Pembelajaran dilakukan seperti pembelajaran sesungguhnya. Evaluasi kelompok kecil ini dilakukan untuk mendapatkan informasi mengenai tanggapan siswa tentang keterbacaan materi dan kemenarikan bahan ajar LKS naskah drama.

Pada evalusi kelompok kecil, angket yang diberikan kepada siswa. Beberapa jumlah pertanyaan yang akan dijawab oleh siswa, untuk mengetahui sikap siswa terhadap bahan ajar LKS naskah drama. Berdasarkan hasil angket uji coba kelompok kecil yang diperoleh, dapat disimpulkan bahwa respons siswa 
terhadap bahan ajar LKS menulis teks drama adalah positif dengan persentase 76.75\%. pada iji coba kelompok ini dapat dikatakan berhasil.

2). Pelaksanaan Uji Coba Lapangan

Pada tahap akhir, yaitu uji coba lapangan. Uji coba dilakukan pada sekolah yang ada di Kabupaten Musi Rawas, untuk mendapatkan informasi yang menyeluruh tentang kualitas produk bahan ajar naskah drama. Hasil dari uji coba lapangan dari beberapa sekolah dapat dilihat hasilnya positif. Siswa merespons baik tentang bahan ajar menulis naskah drama berbasis cerita rakyat Musi Rawas. Hasil penghitungan angket dari beberapa sekolah dapat dilihat dari diagram di bawah ini.

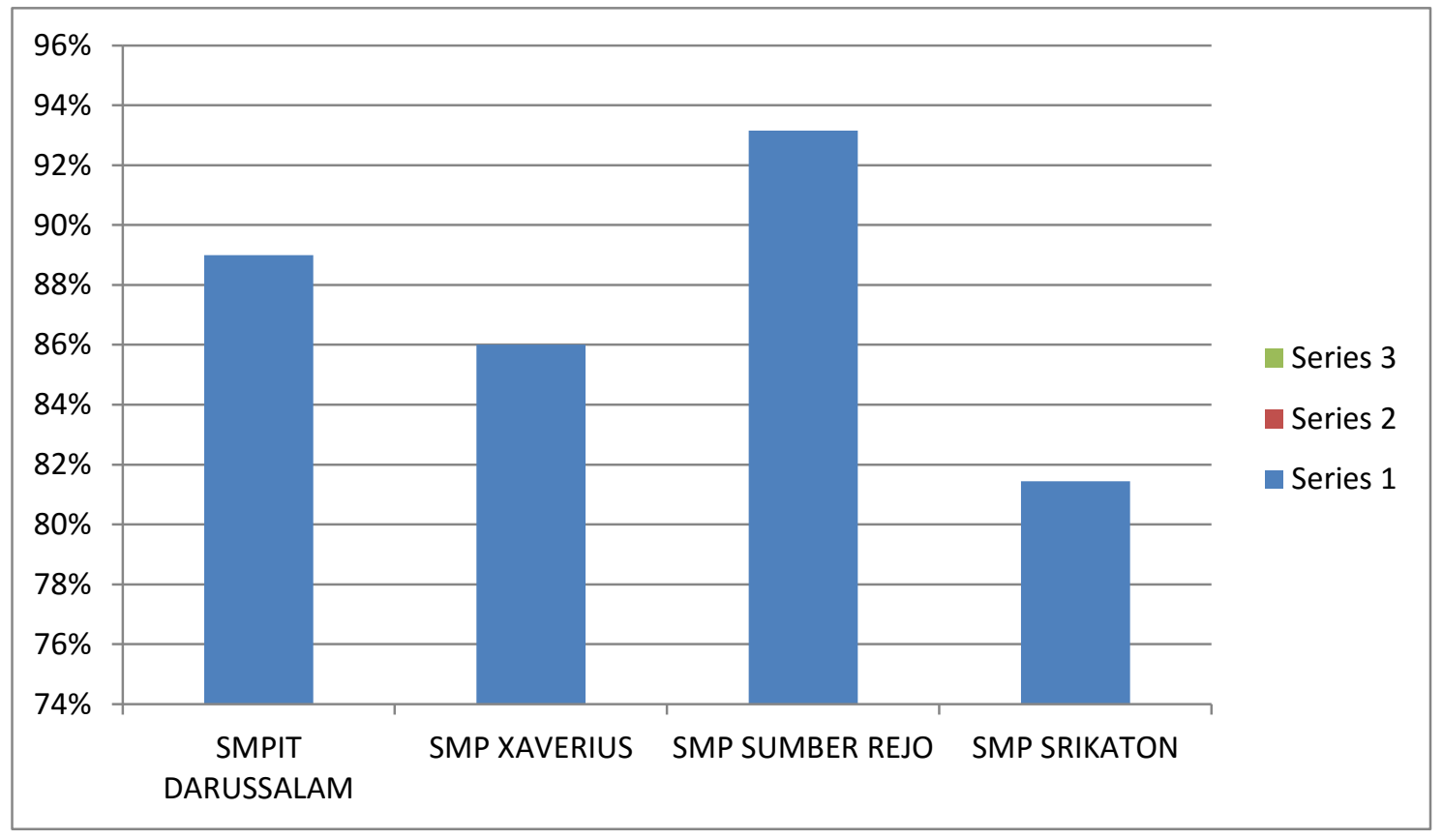

Diagram 1. Hasil Penghitungan Angket Uji Coba Kelompok Besar

\section{Pembahasan}

Produk yang penulis hasilkan dalam penelitian pengembangan ini berupa bahan ajar LKS naskah drama berbasis cerita rakyat Musi Rawas. Materi yang terdapat dalam LKS tersebut adalah menulis naskah drama di kelas VIII. Pembahasan disajikan: 1) proses desain dan pengembangan bahan ajar LKS naskah drama berbasis cerita rakyat Musi Rawas dan 2) mengetahui valid, praktis, dan efektif bahan ajar naskah drama berbasis kearifan lokal. 
Proses desain pengembangan bahan ajar LKS naskah drama dilakukan setelah tahap mengidentifikasi. Tahap mengidengtifiksi dilakukan untuk mengetahui kebutuhan bahan ajar LKS naskah drama. Proses mendesain bahan ajar yaitu menentukan tujuan pembuatan bahan ajar LKS naskah drama berbasis cerita Musi Rawas dan dilanjutkan evaluasi kevalidan, kepratisan, dan keefektifan bahan ajar LKS naskah drama.

Bahan ajar LKS menulis naskah drama dibuat pratis untuk menarik minat belajar siswa. Pada bagian cover diberikan gambar pentasan drama, agar terkesan lebih menarik. Bahan ajar dibuat sesuai dengan karakteristik siswa. Pemilihan cover pada bahan ajar LKS naskah drama harus diperhatikan, agar bahan ajar LKS naskah drama ini dapat menaraik minat belajar siswa. Bahan ajar yang dibuat harus sistematis di bagian awal terdapat kualitas buku, kata pengantar, daftar isi, peta konsep kemudian dilanjutkan dengan materi.

Kegunaan bahan ajar LKS Menulis Naskah Drama Berbasis Cerita Musi Rawas, sebagai berikut: 1) menarik minat siswa agar lebih termotivasi dalam pembelajaran menulis naskah drama; 2) sebagai panduan dalam kegiatan pembelajaran menulis naskah drama; 3) menumbuh kembangkan kreativitas siswa dalam pelajaran menulis naskah drama; dan 4) siswa diharapkan dapat berperan aktif pada kegiatan pembelajaran. Siswa tidak takut untuk bertanya, mengeluarkan pendapat, dan gagasan mengenai materi yang diajarkan. Hal ini sesuai dengan pendapat Amri dan Ahmadi (2010:67), harus memenuhi kriteria yaitu: susunan tampilan, bahasa yang mudah, menguji pemahaman, stimulan, kemudahan dibaca, dan materi instruksional sehingga menghasilkan bahan ajar cetak yang berkualitas.

Evaluasi kevalidan bahan ajar menulis naskah drama dilakukan dengan pengisian instrumen penilaian bahan ajar kepada validator ahli. Evaluasi ini dilakukan oleh tiga ahli, yaitu ahli kebahasaan, ahli kelayakan desain, dan ahli isi/materi. Hasil angket dari para ahli merupakan standar patokan apakah bahan ajar yang dikembangkan valid atau tidak. Berdasarkan analisis angket validasi bahan ajar LKS menulis naskah drama berbasis cerita Musi Rawas dari tiga ahli 
desain, bahasa, dan materi menunjukkan bahwa tingkat kelayakan atau kevalidannya dalam kategori baik, dengan persentase 79,17\%.

Dengan demikian, bahan ajar LKS naskah drama berbasis cerita Musi Rawas yang dikembangkan telah valid. Bahan ajar selanjutnya direvisi sesuai dengan saran-saran dan masukan dari validasi ahli. Setelah diketahui kevalidannya bahan ajar diuji cobakan di sekolah yang ada di Musi Rawas. Kemudian, hasil dari uji coba lapangan dari beberapa sekolah dapat dilihat hasilnya positif. Hal ini dibuktikan dengan siswa merespons baik tentang bahan ajar menulis naskah drama berbasis cerita rakyat Musi Rawas. Keberhasilan pengembangan bahan ajar LKS naskah drama ini juga karena melaksanakan langkah pengembangan dengan model Dick \& Carey (dalam Setyosari, 2013), terdapat sepuluh langkah menurut model Dick and Carey, yaitu: 1) analisis kebutuhan dan tujuan; 2) analisis pembelajaran; 3) analisis pembelajar (siswa) dan konteks; 4) merumuskan tujuan performansi; 5) mengembangkan instrumen; 6) mengembangkan strategi pembelajaran; 7) mengembangkan dan memilih bahan pembelajaran; 8) merancang dan melakukan evaluasi formatif; 9) melakukan revisi; dan 10) evaluasi sumatif. Walaupun, langkah pengembangan dalam penelitiannya ini hanya dibatasi pada langkah ke delapan.

\section{Simpulan}

Berdasarkan hasil penelitian dan pembahasan menunjukkan bahwa validitas bahan ajar LKS menulis naskah drama siswa kelas VIII SMP seKabupaten Musi Rawas termasuk dalam kategori baik dengan persentase $79,17 \%$. Hal ini dibuktikan dari validasi kelayakan desain termasuk dalam kategori baik, dengan persentase $82 \%$; dari ahli kelayakan kebahasaan termasuk dalam kategori baik, dengan persentase $77,14 \%$; dan dari ahli kelayakan isi/materi termasuk dalam kategori baik, dengan persentase 77,14\%. Dengan demikian, validitas bahan ajar LKS menulis naskah drama dalam penelitian ini dapat diterima kebenarannya. Bahan ajar LKS yang dikembangkan telah valid dan bahan ajar LKS setelah diujicobakan di sekolah dapat meningkatkan minat belajar menulis naskah drama siswa kelas VIII SMP se-Musi Rawas. 


\section{Daftar Pustaka}

Amri, S. \& Ahmadi, L. K. (2010). Konstruksi Pengembangan Pembelajaran: Pengaruhnya terhadap Mekanisme dan Praktik Kurikulum. Jakarta: Prestasi Pustaka.

Cahyani, I. (2012). Pembelajaran Menulis Berbasis Karakter dengan Pendekatan Experiental. Bandung: Program Studi Pendidikan Dasar SPS UPI.

Endraswara, S. (2011). Metode Pembelajaran Drama. Yogyakarta: CARS.

Fadhillah, D. (2019). Pengaruh Metode Tebak Kata terhadap Keterampilan Menulis Puisi Siswa Kelas IV SDN Taman Cibodas Kota Tangerang. Silampari Bisa: Jurnal Penelitian Pendidikan Bahasa Indonesia, Daerah, dan Asing, 2(1), 134. doi:10.31540/silamparibisa.v2i1.332

Jannah, M. (2016). Pengembangan LKS Bermain Drama Berbasis Autobiografi Habibie dan Ainun untuk Siswa Kelas XI SMA/MA. Universitas Lampung.

Lasmiyanti, A., Sarwono, S., \& Gumono, G. (2019). Peningkatan Kemampuan Menulis Naskah Drama melalui Pendekatan Kontekstual Berbasis Cerita Rakyat Musi Rawas Siswa Kelas VIII SMP Negeri Pedang. Diksa: Pendidikan Bahasa dan Sastra Indonesia, 5(1), 53-54. doi:10.33369/diksa.v5i1.9443

Noermanzah \& Friantary, H. (2019). Development of Competency-Based Poetry Learning Materials for Class X High Schools. International Journal of Recent Technology and Engineering, 8 (4).

Noermanzah, N. (2015). Peran Dosen Bahasa dan Sastra Indonesia dalam Mempertahankan Bahasa Indonesia sebagai Alat Pemersatu Negara Kesatuan Republik Indonesia pada Era Globalisasi. Dalam Prosiding Seminar Nasional Bulan Bahasa 2015. Unit Penerbitan FKIP Universitas Bengkulu, p. 274. http://repository.unib.ac.id/11133/

Riantiarno, N. (2003). Menyentuh Teater Tanya Jawab Seputar Teater Kita. Jakarta: Sampoerna.

Setyosari, P. (2013). Metode Penelitian Pendidikan dan Pengembangan. Jakarta: Kencana.

Susetyo. (2010). Penelitian Kuantitatif dan PTK. Bengkulu: UNIB.

Tarigan, H. G. (2008). Membaca Sebagai Suatu Keterampilan Berbahasa. Bandung: Angkasa.

Yogananta, D. (2016). Pengembangan Media Pembelajaran Membaca Teks Drama untuk SMP Kelas VIII dengan MTGT (Metode Teams Games Tournament) Berbasis Software Adobe Flash. Universitas Negeri Yogyakarta. 